Article

\title{
Something Super-Wicked This Way Comes: Genre, Emergency, Expectation, and Learning to Die in Climate-Change Scotland
}

\author{
Dominic Hinde \\ Division of Media, Communication and Performing Arts, Queen Margaret University, Edinburgh EH21 6UU, \\ UK; dhinde@qmu.ac.uk
}

Received: 5 June 2019; Accepted: 3 February 2020; Published: 7 February 2020

\begin{abstract}
This article approaches the issue of climate change and the response to it in Scotland from the perspective of genres of expectation and normality, focusing in particular on the relationship between genre, the political imagination, and calls for 'climate realism'. Functioning partly as provocation and partly as a piece of critical theory on the problematic aspects of contemporary genres of expectation in Scotland, it discusses the push for normality as a driving force in the construction of imagined futures in the context of climate change, problematising how this fits with established expectations of the Scottish political imaginary and its futurity. Using the work of the scholar of genre and affect Lauren Berlant and her identification of genre as a means of 'moving on', it considers the idea of materially contingent narratives as an exit strategy from the present moment. To illustrate this, it briefly discusses Jenni Fagan's contemporary climate change novel The Sunlight Pilgrims as an example of 'irrealist' confrontation of climate change and how this relates to the concept of the Anthropocene as an everyday experience. Ultimately, it concludes that contemporary attempts at climate realism require engagement with the irreal material circumstances of climate change and the fundamentally 'super-wicked' nature of climate processes in order to escape the constraints of progress, restoration, and normalisation as genre structures in discussion of climate futures.
\end{abstract}

Keywords: modernity; climate change; climate emergency; new materialism; genre; Scotland

\section{Introduction}

In 2008, an ambitious nationalist Scottish Government keen to set out an agenda for the future unveiled a competition, the Saltire Prize, which would award ten million pounds to the first company to produce marine energy technology "that achieves the greatest volume of electrical output over the set minimum hurdle of 100 GWh over a continuous 2 year period using only the power of the sea" (Scottish Enterprise 2013). A centrepiece in the repositioning of Scotland as a neo-industrial energy superpower, 10 years later, the prize was quietly dropped, as nobody had met the criteria to win it. The expected march of technology and the 'Cinderella renewable' (Flynn 2015) in the bright new Scotland the SNP envisioned, and the anticipated power of enterprise and innovation to create sustainable futures, had demonstrably not come to pass, whilst in the intervening decade the problem it was intended to solve-climate change-would grow verifiably worse.

The prize functioned as part of a general trend within Scottish governance and development toward meeting aspirational future goals through mechanisms of competition and innovation (Everett et al. 2012, p. 113; Jeffrey et al. 2013), whereby the establishment of frames of progress within existing political genres of expectation allowed a future to be constructed in the present, a process which itself required no change to understanding of the underlying issues or the Scottish political imaginary. Governance as the practice of genre in which political levers in the present are used to start 
the autonomous process of achieving future policy goals is a common political tool when building futures, based on the idea that the future will inevitably offer solutions unavailable at the present time and that modernisation is an organic process which will yield positive outcomes based on capitalist frameworks of investment and return. What the hubris and subsequent failure of the Saltire Prize demonstrated was the dissonance between narratives of ecological modernisation and attempts to map the future through aspiration and representation on the one hand, and the increasingly material realities of climate change on the other. With its precarious ontology exposed by the failure of market mechanisms and the effects of climate change the utopian 'good Anthropocene' envisaged by some (see Ellis 2011), in which global environmental change is recontextualised as a series of ecomodernist good news stories about Scotland's place in the world, is suddenly found wanting.

Through the prism of genre as a set of expectations about events to come, I discuss the narrative challenges and disappointments of environmental modernisation in Scotland as a genre trap. Critiquing the certainties it offers, this paper argues that the ongoing realities of climate change and destabilisation of established structures provide a material counterpoint to embedded stories about the potential of capital and modernity as self-solving problems in political and economic projects in Scotland. Such a genre-based approach is useful because of its ability to illuminate the overlap between political, literary, social, and economic imaginaries, and therein provides a common tool to access and bring together diverse but related fields of scholarship across the environmental humanities; most notably literature, political science and history.

To begin this problematisation I first discuss the existence of normalisation and modernisation as genres in Scotland, considering how the paradigm of modernisation theory and linear development is still dominant in contemporary economic and political debates and in ideas of Scotland moving toward a destination embodied in popular discourse. This also includes an examination of the material and conceptual crossovers between modernity and the concept of the Anthropocene, and how they are entangled with one another in material and social terms.

This article then briefly looks at the inherent conflict between this drive for normalisation and the abnormality inherent to climate change, invoking the work of Ingolfur Blühdorn on the "politics of unsustainability" (Blühdorn 2011) and the problems of normalisation as a genre, noting that the 'super-wicked' aspects of climate change require genres which appreciate the material connections between the present and the future. Super-wickedness is used to discuss the idea of materially contingent narratives, drawing on new materialist and non-representational theory. In the light of Michael Löwy's theorisation of irrealism, the article asks what realism means in the context of the inherently 'irreal' futures offered by climate change. It then moves to consider the portrayal of climate disruption, safety and normality in Scotland in Jenni Fagan's near future novel The Sunlight Pilgrims, set in 2020, as an example of the "lived Anthropocene" (LeMenager 2017, p. 221), including discussion of central questions of norms, expectation and narrative progression in the face of climate upheaval in contemporary Scotland.

Finally, the article discusses genre as an exit strategy from the deadlock of climate and focuses in particular in the concept of 'moving on'. In conclusion, it argues that 'being realistic' and attempting to reach points of normalcy in fact involves entertaining the irreal; questioning conventional narrative fulfilment in the Scottish political imaginary to move beyond the epistemological traps into which previous narratives of expectation, modernisation and aspiration have fallen.

\section{Scotland's Modernity and the Path to the Future}

Scotland constitutes a laboratory for narratives of modernity, progress, and expectation due to its status not merely as a self-appointed contemporary sustainability leader but also as an archetype of modernisation which allows it to position sustainability as a competitive advantage and modernising but non-radical force. The idea of Scotland existing on a path toward a future state of improvement is well-established, with David Turnock (1982) describing a narrative of modernisation in Scotland as an ongoing national process well predating its move toward ecological modernisation, whilst David 
McCrone (2017, p. 29) identifies the 20th century as a long and self-conscious period of modernisation in Scotland in which it progresses toward a relative equilibrium alongside other European modernities. In a similar vein, Lindsay Paterson (1994) traces a narrative of restoration and destination in discussions about autonomy and Scottish social development, whilst Tom Nairn has positioned Scotland's national narrative and its national awakening in a European context, emphasising its quest for 'normalcy' as part of a "tidal wave of modernization" (Nairn 1974).

A central pillar of Scotland's relationship to the future is both an expressed desire for normalisation and a need to lay claim to the ideas and structures of modernity itself, being perversely both antecedent and delayed beneficiary of the intellectual and industrial processes of European modernisation. Andrew Blaikie summarises the situation by writing that "the epistemological shifts entailed in comprehending modernity as understood since the Enlightenment have provided the intellectual lens by which 'Scotland' is viewed as an imagined community" (Blaikie 2010, p. 21), placing it within a broad set of historiographic and narrative norms about its status and future in which the construction of modernity is an ongoing project. This elevation of the Scottish modern is felt keenly in Scotland's political life, forming a centrepiece of its desire to become a 'normal' high-modern nation state and to take its place at the table which it feels it partially built. Equally so, this progress toward a destination is precarious and often unclear, with convenient stories being deployed to reconcile the past with the aims of the future. As Scott Hames surmises of devolution and its narratives, 'Scotland has a very uncertain grasp of how it got to where it is going' (Hames 2017, p. 22), with a tendency to retrospectively write deterministic histories to make the present and future fit with the past.

In the context of climate change, Scotland now finds itself engaged in a struggle for a 'green' articulation of this modern (see for example Beck 2010, 2016; Hamilton et al. 2015). Trying to integrate deeply embedded political stories about sovereignty and progress as part of a wider discourse of post-industrial ecological modernisation, there emerges a tendency toward a resurrection of the modern tradition and its requisite genres in the social and political imaginary. This expectation, that modernisation from crisis will yield improvement, thus re-uses a genre which is not fit for purpose. In its efforts to be a climate leader Scotland, once again establishes an unreachable end point in which it is able to solve climate change as part of a march toward an ambiguous destination.

Modernisation and futurity as a teleological project in Scotland have also acted as a revenant, with modernisation strategies aimed at the rectification, restoration or normalisation of Scotland's society and economy yielding unintended results, as evidenced for example by the repeated attempts to 'solve' the greater Glasgow area (Collins and Levitt 2016) and through enforced dislocation and prescriptive reinvention as part of a neo-liberal turn (Boyle et al. 2008), whilst similar rounds of modernisation and the identification of mandated futures have been carried out in rural and peripheral Scotland. Since the inception of the Scottish Parliament, such strategies have also sought to create single coherent pictures of and stories about the future which regard Scotland as a single, absolute unit in which its contradictory needs and demands could be conveniently reconciled in a single narrative box. This modernisation has also been problematised and rebelled against (Blaikie 2010), with cultural responses ranging from the positive to the conservative and pastoral, the nightmarish and the intensely political, not the least in terms of the semiotics of nuclear energy in the public space (Brown 2017; Heffron and Nuttall 2017) and a discussion about the appropriateness of future technologies. These repeated attempts to reclaim, adjust, reconstitute or otherwise develop coherent visions of newer Scotlands which nonetheless seek to restore the country's nominal role as a pioneer are seemingly never ending, writing and re-writing the future as a series of different realisable everydays.

Modernity and its political imaginary have produced a material shadow which traces the path and impact of human processes from climate to particulates and radiation: the Anthropocene. A collective name for the totalising reach of a series of human processes across the globe, including the identification of Anthropocene markers in Scotland (Vane et al. 2011), the Anthropocene as problematique demands a reconsideration of many contemporary modes of understanding and being. Its genesis as a term is based on the identification and mapping of specific material processes, as first 
theorised by Paul Crutzen and Eugene Stoermer in their introduction of the concept to contemporary geology (Crutzen and Stoermer 2000). Though the Anthropocene is at its root a material process, it has also produced what the geographer Jamie Lorimer has labelled an 'Anthropo-scene' (Lorimer 2017), which promotes and demands new modes of praxis across the humanities. The Anthropocene is thus, like the modernity that created it, both material and social. Clive Hamilton describes the relationship between the two as a process of fundamental entanglement dating back to the European (and by implication Scottish) Enlightenment:

Inverting the episteme of eighteenth-century Enlightenment, the new divide of earthly reality into two dimensions separated temporally, ontologically, epistemologically and institutionally constituted the intellectual enclosures in which the sheep of industrial modernity were kept. These enclosures may also have disinhibited the elite of the industrial and imperial order as they pushed humanity and the Earth into the Anthropocene; after all, if nature was now dead—or disenchanted in [Max] Weber's phrase-everything becomes calculable. (Hamilton et al. 2015, p. 6)

Within this entanglement, calculability becomes a great genre trap, trying the invention of the future in both narrative and material terms and reliant on an increasingly tenuous belief in the integrity of a modern mode of being which no longer exists.

The writer and essayist Roy Scranton has summarised this confrontation with the fall of modern calculability as "learning to die in the Anthropocene" and that "learning to die as a civilization means letting go of this particular way of life and its ideas of identity, freedom, success, and progress" (Scranton 2015, p. 24) as part of a new, realist enlightenment. In other words, the Anthropocene means killing all of the assumptions of expectation, progress, and normality inherent to the extant genres of modernity. Scranton's approach to narrative is such that we can no longer tell ourselves stories about a world that does not exist, and where this is now increasingly apparent as an ontological certainty. Convenient ideas about the slow recovery of the 'normal' landscape and economy to a point of order clash with the unfolding crises of warming seas, wildfires, and the ongoing precarity of the political moment.

In 2019, the Scottish Government declared a 'Climate Emergency' (Scottish Government 2019) in response to pressure from activists within and outwith the Scottish National Party, weeks before the highest ever levels of Carbon Dioxide in the earth's atmosphere of 415ppm were recorded (Earth System Research Laboratory 2019). An apparent recognition that climate change was in fact an unfolding exponential problem, this declaration of crisis might initially appear a promising development in terms of re-assessing the expectations around action and resolution of an escalating problem. As the genre theorist Lauren Berlant notes in her discussion of crisis in late modernity and emergency in the contemporary political imaginary, however, it also exposes the pressures faced by 'managerial realism' (Berlant 2011a, p. 257), where deep-seated problems are reduced to crisis in order to make them fit the genre constraints of contemporary politics, and which remains an unsatisfactory mode for effective response. As Berlant expresses it, "the historical present is always a time of transition: but crisis is an emergency in the reproduction of life, a transition that has not found its genres for moving on." (Berlant 2011a, p. 3). Elsewhere, Berlant describes this contemporary moment as a genre impasse:

A genre is a loose affectively-invested zone of expectations about the narrative shape a situation will take. A situation becomes-genre, finds its genres of event. Any historical present is an impasse that appears in multiple temporalities of movements that have anchored themselves to a cluster of conventional genres. (Berlant 2011b, p. 2)

Here, I characterise Scotland as being engaged in such an impasse in relation to the onset of climate change, arguing that its material situation is still yet to find a genre for 'moving on' that is central to the realisation of a political imaginary (and political economy) of the Anthropocene and of the construction of suitable genres and modes of expectation. To do so, I first confront the idea of normalisation and restoration as a defining genre in itself. 


\section{Normalisation in Abnormal Times}

As discussed, contemporary Scotland is often framed in its media and political imagination as engaging in a process of both restoration and normalisation, which seeks to elevate or restore it to what could broadly be considered a normal state of being in its political systems, economic position and the integrity of its landscape. This has been noted by Hearn (2014) as a tension and apparent commensuration between idealist and materialist strands in political projects relating to the 2014 referendum on Scottish independence, and appears repeatedly in pleas to make Scotland a normalised European state. The 2014 white paper on independence, Scotland's Future, for example, created a vision in which the normality of Scotland's economy, relationship with other countries and general status as a "normal independent country" were all repeatedly asserted (Scottish Government 2014, p. 334).

In the context of climate change, however, normality as destination becomes problematic for the simple reason that anthropogenic climate change is not merely abnormal, it shows no signs of resolution or reversal. The latest report by the United Nations Intergovernmental Panel on Climate Change (IPCC 2018) outlines a series of scenarios for a 1.5 degree rise in global temperature, a target which it seems increasingly likely will be missed and that far higher increases are likely in the short term (Watts 2019). Ingolfur Blühdorn describes this striving for development and the attainment of specific benchmarks of progress as "the politics of unsustainability", whereby attempts to develop forms of ecopolitics which strengthen and maintain existing systems are self-defeating because normality is not the necessary state for moving on. Blühdorn agrees that it is all but certain that the benchmarks set by the IPCC cannot be met, but that by continuing to pretend and act as if they will be the political imaginary locks itself into an unsustainable genre trap, what Blühdorn describes as a "curious simultaneity" (Blühdorn 2011, p. 3) regarding the recognition of the need to deal with the material challenges of climate change alongside an embedded refusal to re-write or reconstitute any of the modes of action which underpin the political imaginary.

This firm adherence to the dualistic nature-culture dichotomy of modernity allows Scotland's natural heritage to peacefully coexist with its social practices and socioeconomic structures in unproblematic perpetuity (Hinde 2016a), a place where climate justice is an external rather than domestic concern (Aitken et al. 2016). This means that Scotland's attempts at normalisation and modernisation inevitably replicate what Blühdorn sees as banalisation of environmental crisis as part of the overarching genre of restoration and adaption:

Reports about the worst ever forest fires, longest ever droughts, highest ever deforestation rates, fastest ever species decline, and so forth have become a standard feature of daily news coverage. Just like mass un(der)employment or rapidly increasing wealth differentials, comprehensive environmental change and the incremental consumption of nature have long become a normal, if unpleasant, aspect of modern life. (Blühdorn 2011, p. 37)

Within the genre trap that Blühdorn identifies, such disruptive events become peripheral collateral in a narrative of continuity; the push for normality, restoration or restitution in political projects thus runs counter to the obvious truth that normality as a destination is problematic. In 2018 the IPCC released its fifth assessment report (IPCC 2014), which formed the basis of the Paris climate negotiations. The sixth report, for which the first lead author meeting took place in Edinburgh in 2019, will likely present different and worse scenarios for mitigation and adaption. It is in this context that I argue for the usefulness of engaging with the so-called super-wicked aspects of climate, which are key to understanding the materiality of climate stories and the highly contingent narratives they might seek to develop.

\section{Something Super-Wicked This Way Comes}

Climate change is often described as a "super-wicked" problem (Levin et al. 2009, 2012; Peters 2017) due to its complexity, competing demands and unprecedented scale, as well as its difficult temporality. It does not subscribe to easily tangible ideas of cause and effect, with emissions released 
decades ago having reflexive impacts on future generations and requiring changes in the present which may not directly benefit those alive today. The irony of this is that it is nonetheless talked about in terms of a solvable, quantifiable and calculable risk, in which we are invited to remedy the future if only the political will and correct economic levers can be mobilised. This super-wickedness is also found in the enormity of contemporary industrial strategy, in which Scotland is offered trade-offs and compromises, restarts, growth packages and social contracts, decentralisations, renegotiations, and settlements as a means of grasping at the grail of economic prosperity and social equality always undone or out of reach.

Super-wickedness is a teleological challenge, because it illuminates examples of what Berlant calls "cruel optimism", whereby something which we believe to be to our benefit returns to us in future forms with supremely negative impacts, but this negative effect is a direct result of what we consider immediately positive or, indeed, necessary action. She describes cruel optimism as to "maintain attachment to a significantly problematic object" (Berlant 2011a, p. 25), or to continue to invest expectation in processes, objects and modes of living which are ultimately to the detriment of those attempting to create positive futures for themselves.

In this sense Scotland constitutes such a significantly problematic object, entangled as it is with the super-wicked revenant of the oil industry, which has long been a pillar of economic nationalism and a well-established narrative about Scotland's hidden and hypothetical future wealth (Logan and McNeish 2012; Liñeira and Cetrà 2015, p. 261). The optimism placed in fossil energy in Scotland is a cruel optimism because it fails to recognise the long-term negative impacts on those its promotion ostensibly seeks to help. Super-wickedness as a genre trap is made visible as an inability to articulate the relationship between events in the past, present and future, so that attempts at pragmatism or realistic solutions result in a false realism which fails to accurately grasp this temporally distributed causation, and which can at worst construct deeply unrealistic or anachronistic expectations about what is possible, feasible, or likely.

Inherent to Berlant's understanding of genre is the need to locate more appropriate responses to the contemporary moment by engaging in new forms of realist praxis. Realism as an idiom is already well embedded in discussions of climate, which proposes that 'realistic' actions be taken to deal with global warming and ecological disruption, an approach which demands the presentation of data or knowledge and actions developed in response to this information, but also a public acceptance that we need to be 'realistic' about what can be achieved (Kunelius and Eide 2012). This adherence to the real is, however, often blind to the shared strangeness of the new material circumstances of climate change. Realist approaches to climate change thus vary greatly in their claims to represent, recognise or adhere to the reality of things. Calls for pragmatic realism have for example emerged from radical environmental activist scholars such as Andreas Malm, who has argued for a socialist climate realism (Malm 2018) and the 'dark realism' of Dale Jamieson (2014) which carries elements of resignation, or similarly the fatalism of the literary Dark Mountain Manifesto (Hine and Kingsnorth 2009). Such sobering realist tendencies situate climate change within the development of capitalist modernity and posit a political economy of climate change which must realistically be dealt with through a sober appraisal of its impacts. In Scotland, there has been some discussion of appropriate form of realism and the limits of genre (Little et al. 2018, pp. 12-14), whilst the energy sector and Scottish Government have asserted a desire for their own articulation of realism around the issues of resilience and disaster management, including the development of realistic"' climate measures attainable within current structures (Kirkcaldy 2018). This has also led to a situation in which the renewables industry has been able to follow the same extractive patterns and removal of capital from Scotland as the fossil industry (Campbell 2019) through its mass roll out being portrayed as a 'realistic' approach to fighting climate change.

Concordantly, more radical solutions or imaginaries often remain untouched. Climate realism is a double-edged sword in that it invites us to abandon idealism and grasp the immediate truths of climate change whilst simultaneously constraining discussion within genres of normality, expectation 
and workability. Negotiating this tension between the highly material nature of climate change and the apparent constraints and pitfalls of realism, I consider that there are insights to be gained from non-representational and new materialist approaches to the question of climate futures which necessarily assume materialist perspectives without the constraints of looking only at the present. Such approaches engage directly with the materiality of contemporary events, but also with the connection between contemporary events and future material outcomes exemplified by the delayed feedbacks of climate. There is an assumption within much climate futures that reality is constructed by narrative alone (Paschen and Ison 2014) and within academia on communication and climate change there is an obsession with narratives that 'work' (see for example Bushell et al. 2015, 2017), together with a resulting quest for transformative narratives which might indeed compel the political and economic system to moments of action. This predisposition for representation as a speculative projection assumes that creating the future is a singularly rhetorical project and that stories have only material effect rather than material roots.

Within the framework of material upheaval caused by climate change with which we are already living, however, this model must be reversed to take into account the increasingly hard-to-ignore material aspects of environmental instability and the consequent emergence of materially contingent narratives. One of the peculiarities of the future-to-come in climate terms is that it is a place which can only live through representation and as yet lacks its own materiality, yet the impacts of the future which will emerge and which in many cases are already being felt can be highly dissonant when set against the expectations of both technological and economic progress and the concept of environmental crisis as it is portrayed in popular media and the political imagination. We cannot simply invent any future we like from a standing start, and though all visions of the future are representational, this representational capacity is severely constrained by the materiality of the situation. The new materialist Jessica Schmidt has illustrated this problem in her discussion of the relationship between new materialism and representation as a driver of contingent narratives:

Once theorising (international) politics was concerned with the construction of meaning onto reality through abstraction and a certain detachment from the contingency of reality-not necessarily to 'speak truth' but to appropriate the present and meaningfully influence the future. Today, it seems, it is this contingency of reality, in its productive and performative capacities, that dictates theorising (and its limits or impossibility). (Schmidt 2013, p. 177)

As outlined, at present, Scotland relies heavily on expectations about narrative fulfilment where the material reality is secondary to the expectation of what may happen. The idea that story can shape reality becomes secondary to the hammering of materialisms on the door of linear and prescriptive narratives. In Scotland, where politics like to portray the future as a semi-utopian undertaking as part of the 'new Scottish politics', but where reforms and dreams remain unrealised (Cairney 2015, p. 2), the belief that futures are there to be seized through some careful waymarking of the future in the political imaginary is rendered void. As this relates to climate, there is instead a need to entertain the inherently abnormal realities through climate irrealism over realism, one in which reality is abnormal and fantasy normal, discussed in the next section.

\section{The Sunlight Pilgrims and the Prospect of a Scottish Climate (Ir)Realism}

Jenni Fagan's novel The Sunlight Pilgrims (2016) is an example of an everyday climate change narrative focused not on the international implications of the climate emergency or the actions of policy makers or scientists as protagonists, but on the experience of climate breakdown in a peripheral and banal setting. Paying particular attention to its irreal elements and the dissonance between the enforced normalcy and frames of expectation experienced by some of the characters during climate breakdown with the reality of what is occurring, it constitutes an example of Stefanie LeMenager's concept of the 'everyday Anthropocene', whereby globally inconsequential and highly personal events are brought to the fore. LeMenager describes the everyday as "getting by, living alongside the world, 
living through it" (LeMenager 2017, p. 221), and the novel is useful as an access point to unlocking this banal Anthropocene. This is not because it represents any political narrative or viewpoint, nor as an example of complex storytelling at scale but rather because of the way in which it fuses these aforementioned banal aspects of the everyday with the irreal materiality of climate change in a Scottish context, corresponding to Michael Löwy's theorising of irrealism as "work that does not follow the rules of the exact representation of life" but which is "linked to the dream of another world, imaginary, idealised or terrifying" through which reality can best be grasped (Löwy 2009, p. 55). Additionally, the novel contains satirical elements relating to the patterns of management and expectation of unfolding crisis which further expose the precarity of contemporary modes of narrative.

Based in part on scientific research on what hypothetical climate shock might look like, upon its release the novel was immediately classified as a piece of climate fiction (Carpenter 2018), but it is also a study in poverty and precarity, small-town Scotland (and in even more timely fashion, also an explicitly queer narrative due to the presence of a trans teenage girl at its centre). Set largely in the proto-Highland village of Clachan Fells, a place ambiguously and simultaneously in the mountains and by the sea, it plays out against the backdrop of an apparently unstoppable and unknowable winter enveloping Europe as a result of Arctic melting and disruption of the Gulf Stream. This transformation is assumed to be a result of anthropogenic climate change, yet the novel is focused heavily not on the causes or macropolitics of the situation but the residents of Clachan Fells as they grapple with the transformations occurring around them and become increasingly self-reliant. It provides a literary articulation of what the new materialist geographer Hayden Lorimer (2019) has called "the lifeworlds of place", in which the representational structures of the world outside give way to an intense and materially focused localism, with the narrative emerging from the materiality of the weather rather than being imposed as a framework of understanding.

This dissonance between the media of modernity as an environing tool and the elemental media of climate is laid bare by Fagan. The broadcast media attempts to impose meaning according to the conventional genres of news reporting, but these reports increasingly function as disaster commentary rather than as a structuring force for reality; things begin slowly to unravel and the novel advances in line with the plummeting temperatures as awareness of what is underway becomes increasingly contingent on local events. At one point, a news report tells the residents of Clachan Fells that

The entire planet is being impacted by the collapse of intricate weather systems that are vital to survival, just a few degrees lower than is manageable for human habitation, and we could be plunging into a new Ice Age. (Fagan 2016, p. 272)

The news media in the novel is speculative but also fragmentary. Its updates come as interludes in the real experiences of its characters, offering some context but being of little relevance to the material situation in which the residents of Clachan Fells find themselves. Though it is fiction, the highly irreal climate breakdown in the novel is nonetheless materially contingent. The collapse of the infrastructures of modernity, from ease of travel to communications networks, provide a return to the everyday Anthropocene in which the irreal effects of climate breakdown are centre stage. The Sunlight Pilgrims does not grant its characters any kind of post-apocalyptic renewal or catharsis, nor much agency, instead leaving its composite Scotland facing a seemingly unending freeze that is largely beyond understanding, and for which no genre exists beyond the everyday. There is no return to nature or rebalancing of the landscape, no rescue team or rebuilding, and no didactic denouement. The conclusion of the novel is ambiguous, offering some expectation of a return to spring but also describing its main character's flirtation with sleep and hypothermia. The novel is thus also, in a very literal sense, an example of Scranton's process of learning to die in the Anthropocene.

A central motif of The Sunlight Pilgrims is the movement of an Arctic iceberg south into Scotland's waters and the media's fascination with this cryospheric dislocation, an event partially mirrored in reality by the sudden appearance of Arctic wildlife in Scotland as a result of climate change. In 2018, the Scottish media reported the appearance of 'Wally the Walrus' in the Hebrides, alongside bearded Arctic 
seals more habitually found closer to the pole (McKenzie 2018). There may not (yet) be icebergs floating south, but climate change and Arctic warming are already having nominally abnormal impacts on Scotland, whilst disruption to the hydrological cycle and extreme weather events are already material realities (McGrane et al. 2018). Although the weather events portrayed in The Sunlight Pilgrims are unprecedented and extreme, they are also possible material realities rather than millenarian allegory.

Key in Fagan's portrayal of climate breakdown is the aforementioned attempt to maintain order in the face of slow crisis and the constant promise of restoration. A particularly telling episode involves shoppers becoming trapped at a branch of the Swedish home chain IKEA outside of Edinburgh, a symbol of post-industrial 'normalcy' and renewal built on a former colliery, which is supposed to have reinvigorated the local economy and provided sustainable jobs. IKEA has been widely recognised as both a cultural marker for the expansion of consumerist modernity into post-industrial space (Lindqvist 2009) and, through its products, as a prime contributor to the future archaeology of modernity (Harrison and Schofield 2010, pp. 164-66). In Fagan's climate narrative, the IKEA store becomes a totemic site of enforced normalcy and pretence in contrast to the unravelling world outside, playing on its peculiar semiotic as a place of order and certainty. Fagan herself has talked about the choice of the clean, bright, and expressly modernist consumer experience as a surreal space, saying,

It has that quality of [Michel] Houellebecq and [JG] Ballard and the weird sensation of directing large amounts of confused people through a strange experience. It is a bit like an airport. (Hinde 2016a)

Fagan, who was raised partly on a caravan park adjacent to the present IKEA Edinburgh site when it was a derelict colliery from the defunct Midlothian coal fields, plays with the neat reinvention of the place in a whitewashed and shiny manifestation of the new economy and its happy, re-skilled workers. As snow continues to set in beyond the superstore car park, staff are deployed to cheerily sing songs as a means of lifting the mood, and the IKEA canteen transforms into a temporary ration station for Scotland's climate refugees.

The near-future Scotland portrayed in The Sunlight Pilgrims is thus irreal yet increasingly plausible. Its village in the mountains by the sea is prototypical and yet spatially uncertain, and its characters flit between engagement with the banal everyday aspect of Scotland and the overwhelming experience of catastrophic environmental change, but it is not a grand narrative. This duality is prescient of the new materialism of climate change and the queering of the certainties of modernity, as the backdrop on which it is painted itself begins to move and to be reconstituted in new forms. As Fagan apparently suggests in The Sunlight Pilgrims, the new material circumstances of climate change demand an irrealist genre. These circumstances entail changes to spatial relations, to landscapes and to people. Ultimately, it is in this combination of embodied experience and irreal narrative that the future is best approximated, not merely in terms of utopian alternatives but in terms of its everyday banalities. It is a reminder, to use the words of Stephanie LeMenager, that in the struggle for genre, "nature is not an externality" (LeMenager 2017, p. 221) and presses down on us with increasing weight.

\section{Exit Strategies and Moving on}

Feeling this weight of material circumstance and re-assessing genres of expectation around climate by engaging with its incalculability can, I have argued in this article, function as an exit strategy from the present moment and its future consequences. Such irrealism recognises that things are no longer normal, finding parallels in Judith Halberstam's idea of a pragmatic queer materialism (Halberstam 2005) which offers different modes of constructing understandings of temporality and identity beyond the expectations of the chronological stations of representational life narratives. Halberstam envisions such disruption to expected narratives as symptomatic of a wider ability to challenge genres of expectation with regard to time and its progressions in the context of ecological breakdown and the established genres of modernity. When modernity itself fails as the structural web for political storytelling, a queering takes place. This reflects what Daniel Botkin (1990), for example, 
labels discordant harmonies, as new ecologies emerge which do not subscribe to the concrete baselines of nature as understood within modernity. Rather than being problematic or obstructive, however, such queer renderings of the future provide a remarkably pragmatic avenue to the illustration and subsequent negotiation of future risks.

Such recognition of the inherent non-normativity, of the transgressive and necessary difference, in climate change thus offers an illustration of how, in Lauren Berlant's words, it is possible to 'move on'. The typology of modernity and its concept of what is practical and real, and what is to be expected, fully dictates the formation of future responses to climate change and other challenges, and the understanding of the scope of our ability to deal with them. In reality, however, as the late theorist and critic Mark Fisher succinctly stated with regard to collapse, "There is no punctual moment of disaster; the world doesn't end with a bang, it winks out, unravels, gradually falls apart" (Fisher 2009, p. 2). Even in moments of crisis, banality endures as bureaucracies unfold and struggle to preserve themselves.

In Scotland this precarity is everywhere and yet remains at least partially obscured by genre. The near total collapse of the global financial system in 2008 for example, including the flagship Royal Bank of Scotland that had benefited from the Scottish energy-boom and continues to normalise the concept of recovery in Scottish fossil industries (Askeland 2016), was generally not recognised as a moment of historical cleavage. Even so, it led to widespread uncertainty and was the first time in its history that the bank had suffered such a loss (Law and Mooney 2010, p. 151). Despite this seismic upheaval, little connection was made between the unravelling of the financial system and the everyday struggles of its victims. Disaster is upon us not as a media spectacle or haunting threat but as an anodyne everyday. Our ability to imagine a world beyond it extends only to our ability to posit actionable advice in ten-year time frames. Fisher wrote that "Being 'realistic' may once have meant coming to terms with a reality experienced as solid and immovable. Capitalist realism, however, entails subordinating oneself to a reality that is infinitely plastic, capable of reconfiguring itself at any moment", (p. 54) where the increasingly apparent effects of climate change co-exist with rather than disrupting the pragmatic march toward normality and maintenance. With this in mind, I have argued ultimately that Scotland requires an irreal political imaginary in order to grasp the highly material dimensions of its own situation, but not as utopianism or unserious genres of pastiche or satire. Instead the unrealities of the future and the genres required are altogether different in their management of expectation and what is both desirable and likely. To be modern or contemporary under climate change is to be both familiar and foreign at the same time, queered, reflexive and disruptive.

In 2019, more than a decade and multiple gigatons of carbon on from its birth, the Scottish Government relaunched the Saltire Prize, this time in the form of a more conventional form of government subsidy and with less hubristic aims. It nevertheless followed the same basic genre assumption of economic return and technological fulfilment as its failed predecessor. With the declaration of a climate emergency, the gap between the comfort of modern modes of envisioning the future and the material realities which form its contingent narratives was thus one again exposed. Being realistic in the face of climate change and confronting its super-wickedness is to a high degree a question of embracing material circumstance, and of creating genres not of expectation but of confrontation, being realistic about both how irreal and different the future will be. In such a way we might avoid the traps and pitfalls of modernistic certainty as we seek to avoid a continuation of the politics of unsustainability and instead understand that 'moving on' does not merely involve identifying a destination and assuming that it will be reached, but finding genres to deal with the material changes in which we are already deeply entangled. Ultimately, it is claims to realism and pragmatism which prove false, and an acknowledgment of how compromised we already are by material circumstance that might form the basis of a genre suited to the super-wicked revenants heading our way.

Funding: This research received no funding.

Conflicts of Interest: The author declares no conflicts of interest. 


\section{References}

Aitken, Mhairi, Ben Christman, Mike Bonaventura, Dan Van der Horst, and Julian Holbrook. 2016. Climate justice begins at home: Conceptual, pragmatic and transformative approaches to climate justice in Scotland. Scottish Affairs 25: 225-52. [CrossRef]

Askeland, Errika. 2016. RBS is here to stay. The Press and Journal, August 17. Available online: https://www. pressandjournal.co.uk/fp/business/scotland-business/1000997/ross-mcewan-rbs-is-here-to-stay/ (accessed on 6 February 2020).

Beck, Ulrich. 2010. Climate for Change, or How to Create a Green Modernity? Theory, Culture \& Society 27: 254-66. [CrossRef]

Beck, Ulrich. 2016. Die Metamorphose der Welt. Berlin: Suhrkamp Verlag.

Berlant, Lauren. 2011a. Cruel Optimism. Durham: Duke University Press.

Berlant, Lauren. 2011b. Austerity, precarity, awkwardness. Supervalent Thought. Available online: https: //supervalentthought.files.wordpress.com/2011/12/berlant-aaa-2011final.pdf (accessed on 6 February 2020).

Blaikie, Andrew. 2010. The Scots Imagination and Modern Memory. Edinburgh: Edinburgh University Press.

Blühdorn, Ingolfur. 2011. The politics of unsustainability: COP15, post-ecologism, and the ecological paradox. Organization \& Environment 24: 34-53.

Botkin, Daniel. 1990. Discordant Harmonies: A New Ecology for the Twenty-First Century. Oxford: Oxford University Press.

Boyle, Mark, Christopher McWilliams, and Gareth Rice. 2008. The spatialities of actually existing neoliberalism in Glasgow, 1977 to present. Geografiska Annaler: Series B, Human Geography 90: 313-25. [CrossRef]

Brown, Antje. 2017. The dynamics of frame-bridging: exploring the nuclear discourse in Scotland. Scottish Affairs 26: 194-211. [CrossRef]

Bushell, Simon, Geraldine Satre Buisson, and Mark Workman. 2015. A unified narrative for climate change. Nature Climate Change 5: 971-73. [CrossRef]

Bushell, Simon, Geraldine Satre Buisson, Mark Workman, and Thomas Colley. 2017. Strategic narratives in climate change: Towards a unifying narrative to address the action gap on climate change. Energy Research $\mathcal{E}$ Social Science 28: 39-49.

Cairney, Paul. 2015. Scotland's Future Political System. The Political Quarterly 86: 217-25. [CrossRef]

Campbell, Alexandra. 2019. Extractive Poetics: Marine Energies in Scottish Literature. Humanities 8: 16. [CrossRef]

Carpenter, Stephanie. 2018. The End of the World as We Know It: Four Novels of Climate Change. The Missouri Review 41: 170-83. [CrossRef]

Collins, Chris, and Ian Levitt. 2016. The 'modernisation' of Scotland and its impact on Glasgow, 1955-1979: unwanted side effects and vulnerabilities. Scottish Affairs 25: 294-316. [CrossRef]

Crutzen, Paul, and Eugene Stoermer. 2000. Global change newsletter. The Anthropocene 41: 17-18.

Earth System Research Laboratory. 2019. Trends in Atmospheric Carbon Dioxide. Available online: https: //www.esrl.noaa.gov/gmd/ccgg/trends/data.html (accessed on 6 February 2020).

Ellis, Erle. 2011. The Planet of no Return: Human resilience on an artificial earth. Breakthrough Journal 2: 39-44.

Everett, Bryony, Erika Wagner, and Christopher Barnett. 2012. Using innovation prizes to achieve the millennium development goals. Innovations: Technology, Governance, Globalization 7: 107-14. [CrossRef]

Fagan, Jenni. 2016. The Sunlight Pilgrims: A Novel. London: Hogarth.

Fisher, Mark. 2009. Capitalist Realism: Is There no Alternative? London: Zero Books.

Flynn, Brendan. 2015. Ecological modernisation of a 'Cinderella renewable’? The emerging politics of global ocean energy. Environmental Politics 24: 249-69. [CrossRef]

Halberstam, Judith (Jack). 2005. Queer Temporality and Postmodern Geographies. In A Queer Time and Place: Transgender Bodies, Subcultural Lives. New York: NYU Press, pp. 1-21.

Hames, Scott. 2017. Narrating Devolution: Politics and/as Scottish Fiction. C21 Literature: Journal of 21st Century Writings 5. [CrossRef]

Hamilton, Clive, Christophe Bonneuil, and Francois Gemenne. 2015. Thinking the Anthropocene. In The Anthropocene and the Global Environmental Crisis. London: Routledge, pp. 1-13.

Harrison, Rodney, and John Schofield. 2010. After Modernity: Archaeological Approaches to the Contemporary Past. Oxford: Oxford University Press. 
Hearn, Jonathan. 2014. Nationalism and Normality: A Comment on the Scottish Independence Referendum. Dialectical Anthropology 38: 505-12. [CrossRef]

Heffron, Raphael, and William Nuttall. 2017. Scotland, Nuclear Energy Policy and Independence. In A Critical Review of Scottish Renewable and Low Carbon Energy Policy. Cham: Palgrave Macmillan.

Hinde, Dominic. 2016a. It's Our Environment: Two Terms of SNP Environmental Policy. Scottish Affairs 25: 83-102. [CrossRef]

Hinde, Dominic. 2016b. Jenny Fagan on the Sunlight Pilgrims. The Skinny, March 24. Available online: https://www.theskinny.co.uk/books/features/sunlight-pilgrims (accessed on 6 February 2020).

Hine, Dougald, and Paul Kingsnorth. 2009. Uncivilisation: The Dark Mountain Manifesto. The Dark Mountain Project. Available online: http://dark-mountain.net/about/manifesto (accessed on 6 February 2020).

IPCC. 2014. Climate Change 2014: Synthesis Report. Contribution of Working Groups I, II and III to the Fifth Assessment Report of the Intergovernmental Panel on Climate Change. Geneva: IPCC.

IPCC. 2018. Global Warming of $1.5^{\circ} \mathrm{C}$. An IPCC Special Report on the Impacts of Global Warming of $1.5^{\circ} \mathrm{C}$ above Pre-Industrial Levels and Related Global Greenhouse Gas Emission Pathways, in the Context of Strengthening the Global Response to the Threat of Climate Change, Sustainable Development, and Efforts to Eradicate Poverty. Geneva: IPCC.

Jamieson, Dale. 2014. Reason in a Dark Time: Why the Struggle against Climate Change Failed-and What it Means for our Future. Oxford: Oxford University Press.

Jeffrey, Henry, Bridged Jay, and Mark Winskel. 2013. Accelerating the development of marine energy: Exploring the prospects, benefits and challenges. Technological Forecasting and Social Change 80: 1306-16. [CrossRef]

Kirkcaldy, Liam. 2018. Campaigners express disappointment with scale of ambition in climate change plan. Holyrood Magazine, March 2. Available online: https:/www.holyrood.com/articles/news/campaignersexpress-disappointment-scale-ambition-climate-change-plan (accessed on 6 February 2020).

Kunelius, Ritso, and Elisabeth Eide. 2012. Moment of hope, mode of realism: On the dynamics of a transnational journalistic field during UN climate change summits. International Journal of Communication 6: 266-85.

Law, Alex, and Gerry Mooney. 2010. Financialisation and Proletarianisation: Changing Landscapes of Neoliberal Scotland. In NeoLiberal Scotland: Class and Society in a Stateless Nation. Edited by Patricia McCafferty and David Miller. Cambridge: Cambridge Scholars.

LeMenager, Stephanie. 2017. Climate Change and the Struggle for Genre in Anthropocene Reading: Literary History in Geologic Times. Edited by Tobias Menely and Jesse Oak Taylor. University Park: The Pennsylvania State University Press, pp. 220-38.

Levin, Kelly, Cashore Benjamin, Steven Bernstein, and Graeme Auld. 2009. Playing it forward: Path dependency, progressive incrementalism, and the 'Super Wicked'problem of global climate change. IOP Conference Series: Earth and Environmental Science 6: 502002. [CrossRef]

Levin, Kelly, Cashore Benjamin, Steven Bernstein, and Graeme Auld. 2012. Overcoming the tragedy of super wicked problems: constraining our future selves to ameliorate global climate change. Policy Sciences 45: 123-52. [CrossRef]

Lindqvist, Ulrika. 2009. The Cultural Archive of the IKEA Store. Space and Culture 12: 43-62. [CrossRef]

Liñeira, Robert, and Daniel Cetrà. 2015. The independence case in comparative perspective. The Political Quarterly 86: 257-64. [CrossRef]

Little, Gavin, Graeme MacDonald, and Hannes Stephan. 2018. The Royal Society of Edinburgh Research Network in the Arts and Humanities Connecting with a Low-Carbon Scotland: Disciplinary and Interdisciplinary Reports, Recommendations and Research Questions. Edinburgh: RSE.

Logan, Owen, and John Andrew McNeish. 2012. Flammable Societies: Studies on the Socio-Economics of Oil and Gas. London: Pluto Press.

Lorimer, Jamie. 2017. The Anthropo-scene: A guide for the perplexed. Social Studies of Science 47: 117-42. [CrossRef] [PubMed]

Lorimer, Hayden. 2019. Dear departed: Writing the lifeworlds of place. Transactions of the Institute of British Geographers 44: 331-45. [CrossRef]

Löwy, Michael. 2009. Critical Irrealism. Actuel Marx 1: 52-65. [CrossRef]

Malm, Andreas. 2018. The Progress of This Storm: Nature and Society in a Warming World. London: Verso Books.

McCrone, David. 2017. The New Sociology of Scotland. London: Sage. 
McGrane, Scott J., Grant J. Allan, and Graeme Roy. 2018. Water as an economic resource and the impacts of climate change on the hydrosphere, regional economies and Scotland. Fraser of Allander Economic Commentary 42: 53-74.

McKenzie, Steven. 2018. Arctic Walrus Wally Spotted at Kinlochbervie. BBC Scotland News, May 16. Available online: https://www.bbc.com/news/uk-scotland-highlands-islands-44144249 (accessed on 6 February 2020).

Nairn, Tom. 1974. Scotland and Europe. New Left Review 83: 57.

Paschen, Jana Azinja, and Ray Ison. 2014. Narrative research in climate change adaptation-Exploring a complementary paradigm for research and governance. Research Policy 43: 1083-92. [CrossRef]

Paterson, Lindsay. 1994. The Autonomy of Modern Scotland. Edinburgh: Edinburgh University Press.

Peters, B. Guy. 2017. What is so wicked about wicked problems? A conceptual analysis and a research program. Policy and Society 36: 385-96. [CrossRef]

Schmidt, Jennifer. 2013. The empirical falsity of the human subject: New materialism, climate change and the shared critique of artifice. Resilience 1: 174-92. [CrossRef]

Scottish Enterprise. 2013. Four Marine Energy Firms vie for World Leading Saltire Prize. Press Release. Available online: https://www.scottish-enterprise-mediacentre.com/news/four-marine-energy-firms-vie-for10m-saltire-prize (accessed on 6 February 2020).

Scottish Government. 2014. Scotland's Future: Your Guide to an Independent Scotland. Available online: https://www2.gov.scot/resource/0043/00439021.pdf (accessed on 6 February 2020).

Scottish Government. 2019. Scotland Will Go Greener, Faster with World-Leading Targets. Press Release. Available online: https://www.gov.scot/news/climate-change-action-1/ (accessed on 6 February 2020).

Scranton, Roy. 2015. Learning to Die in the Anthropocene: Reflections on the End of a Civilization. San Francisco: City Lights Publishers.

Turnock, David. 1982. The Historical Geography of Scotland since 1707: Geographical Aspects of Modernisation (Cambridge Studies in Historical Geography). Cambridge: Cambridge University Press. [CrossRef]

Vane, Christopher, Simon Chenery, Ian Harrison, Alexander Kim, Vicki Moss-Hayes, and Jones David. 2011. Chemical signatures of the Anthropocene in the Clyde estuary, UK: sediment-hosted Pb, 207/206Pb, total petroleum hydrocarbon, polyaromatic hydrocarbon and polychlorinated biphenyl pollution records. Philosophical Transactions of the Royal Society A: Mathematical, Physical and Engineering Sciences 369: 1085-111. [CrossRef] [PubMed]

Watts, Johnathan. 2019. Met Office: global warming could exceed 1.5C within five years. The Guardian, February 6. Available online: https://www.theguardian.com/environment/2019/feb/06/met-office-global-warming-couldexceed-1-point-5-c-in-five-years (accessed on 6 February 2020).

(C) 2020 by the author. Licensee MDPI, Basel, Switzerland. This article is an open access article distributed under the terms and conditions of the Creative Commons Attribution (CC BY) license (http://creativecommons.org/licenses/by/4.0/). 